\title{
ЭЛЕКТРОХИМИЧЕСКАЯ РАБОТОСПОСОБНОСТЬ ЛИГНИНА КЛАСОНА В КАЧЕСТВЕ МАТЕРИАЛА ПОЛОЖИТЕЛЬНОГО ЭЛЕКТРОДА ЛИТИЕВОГО ИСТОЧНИКА ТОКА
}

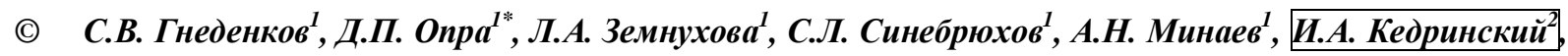 \\ В.И. Сергиенко \\ ${ }^{1}$ Институт химии Дальневосточного отделения РАН, пр. 100-летия \\ Владивостока, 159, Владивосток, 690022 (Россия), e-mail: ayacks@mail.ru \\ ${ }^{2}$ Сибирский государственный технологический университет, пр. Мира, 82, \\ Красноярск, 660049 (Россия)
}

\begin{abstract}
Оценена возможность использования лигнина Класона, выделенного из шелухи гречихи (род Fagópyrum Mill.), в качестве катодного материала литиевого химического источника тока. С использованием взаимодополняющего комплекса методов исследования, а именно энергодисперсионного анализа, сканирующей электронной микроскопии электрохимической имедансной спектроскопии и термогравиметрического анализа исследованы элементный состав, морфологическая микроструктура, электропроводность и термическое поведение лигнина Класона. Посредством гальваностатического разряда при плотностях тока 75 и 100 мкА/см² при комнатной температуре изучены электрические эксплуатационные параметры системы литий/лигнин. Исследовано влияние степени измельчения материала катода на электрохимические характеристики литиевого источника тока. Установлено, что удельная разрядная емкость лигнина достигает 600 мА·ч/г (относительно $\mathrm{Li} / \mathrm{Li}^{+}$). Дополнительная термообработка катода при $250{ }^{\circ} \mathrm{C}$ увеличивает удельную практическую емкость в диапазоне от 3,4 до 0,9 В на $30 \%$. Показано, что значение напряжения разомкнутой цепи не зависит от температуры обработки катодного материала и составляет 3,4 В. В то же время установлено повышение величины разрядного напряжения и, следовательно, мощности электрохимической системы в результате выдержки катода при $250{ }^{\circ} \mathrm{C}$. Предложены и обоснованы токообразующие реакции, протекающие в электрохимическом элементе литий/лигнин. Полученные данные в сочетании с низкой себестоимостью лигнина позволяют говорить о перспективности использования разработанного литиевого химического источника тока системы литий/лигнин Класона в маломощных электротехнических устройствах различного назначения.

Ключевые слова: лигнин Класона, литиевый источник тока, органический электродный материал, шелуха гречихи.

Работа поддержана Правительством Российской Федерации (грант №02.G25.31.0035), а также Дальневосточным отделением Российской академии наук (грант №12-I-П3-01). Один из авторов, Д.П. Опра, является победителем конкурса на получение стипендии Президента Российской Федерачии молодым ученым и аспирантам 2013-2014 г2. (грант №СП-2593.2013.1).
\end{abstract}

\section{Введение}

Широко применяемые литиевые источники тока (ЛИТ) с катодными материалами на основе неорганических соединений обладают повышенными эксплуатационными характеристиками по сравнению

Гнеденков Сергей Васильевич - заместитель директора по научной работе, заведующий лабораторией нестационарных поверхностных процессов, доктор химических наук, профессор, тел.: (4232) 31-38-01, e-mail: svg21@ @otmail.com

Опра Денис Павлович - научный сотрудник лаборатории нестационарных поверхностных процессов, кандидат химических наук, e-mail: ayacks@ mail.ru

Окончание на с. 240. с прочими электрохимическими системами. В то же время материальная база для их производства ограничена, поскольку многие природные ресурсы, используемые в качестве активных составляющих катодов ЛИТ, являются исчерпаемыми и невозобновляемыми [1-3]. Помимо всего прочего, добыча, а также утилизация выработавших свой ресурс неорганических материалов, служа-

\footnotetext{
* Автор, с которым следует вести переписку.
} 
щих положительными электродами ЛИТ, сопровождаются существенными выбросами $\mathrm{CO}_{2}(70-100$ кг на 1 кВт·ч) [4-6]. Эффективность современных ЛИТ, таким образом, недостаточна, и разработка новых нетоксичных электродных материалов, характеризующихся низкой себестоимостью и высокой экологичностью производства, является актуальной задачей XXI века.

Перспективную альтернативу неорганическим катодным материалам для экологически безопасного производства высокотехнологичных современных химических источников электрической энергии представляют органические соединения, получаемые из возобновляемого природного сырья [1, 2, 7-9].

Недавно в [10] было показано, что лигнин, образующийся при сульфитном способе делигнификации древесины, может быть использован в качестве активной составляющей органического катодного материала электрохимического источника тока. Применение в ЛИТ гидролизного лигнина предложено авторами работ [11-16]. Явными преимуществами лигнина перед прочими электродными материалами являются огромный и невостребованный мировой запас, постоянная пополняемость ресурса и низкая себестоимость. В то же время указанные способы [10-16] получения катодных материалов основаны на использовании технических лигнинов, представляющих собой побочный продукт химической переработки различных видов древесного сырья. Следует отметить, что технические лигнины в зависимости от режима получения, типа прекурсора и прочих условий значительно отличаются друг от друга. Проблема воспроизводимости способа получения сырья для катодного материала ЛИТ, стандартизации его состава и структуры существенно влияет на возможность применения лигнина в сфере высокотехнологичного производства. Перспективным источником лигнина, характеризующегося постоянством состава, являются возобновляемые многотоннажные растительные отходы зерновых культур [17]. Однако свойства растительных лигнинов изучены недостаточно [18].

Цель настоящей работы - исследование электрохимических параметров лигнина Класона, выделенного из шелухи гречихи (ЛГШ), оценка возможности его использования в литиевых химических источниках тока.

\section{Экспериментальная часть}

Исходным сырьем для получения лигнина являлись плодовые оболочки (шелуха, лузга) гречихи рода Fagópyrum Mill., выращенной на территории Дальнего Востока (г. Дальнереченск, урожай 2002, 2010 и 2012 гг.). Фракция с размером частиц не менее 2 мм отбиралась посредством просеивания шелухи сквозь сито. Сырье промывали водой, сушили на воздухе, удаляли жиро-восковые вещества. Полученный продукт использовали для получения лигнина Класона посредством обработки 72\%-ной $\mathrm{H}_{2} \mathrm{SO}_{4}$ согласно [19]. Выход лигнина составлял 33-35\% по отношению к массе исходного продукта.

Элементный анализ лигнина проведен на энергодисперсионном рентгенофлуоресцентном спектрометре EDX 800HS (Shimadzu, Япония). Термическое поведение материалов изучено на термогравиметрическом/дифференциально-термическом анализаторе DTG-60H (Shimadzu, Япония). Скорость и максимальная температура нагрева $(T)$ составляли $2,5^{\circ}$ минн и $500{ }^{\circ} \mathrm{C}$ соответственно. Испытания проводились в атмосфере воздуха в открытых платиновых тиглях в динамическом режиме. Полученные данные обрабатыва-

Земнухова Людмила Алексеевна - заведующий лабораторией химии редких металлов, доктор химических наук, профессор, тел. (4232) 21-52-75,

e-mail: laz@ich.dvo.ru

Синебрюхов Сергей Леонидович - ведущий научный сотрудник лаборатории нестационарных поверхностных процессов, доктор химических наук, доцент, тел. (4232) 31-25-88, e-mail: sls@ich.dvo.ru

Минаев Александр Николаевич - главный научный сотрудник лаборатории нестационарных поверхностных процессов, доктор технических наук, профессор, e-mail: aminaev@mail.ru

Кедринский Илья Анатольевич - доктор химических наук, профессор кафедры аналитической химии Сергиенко Валентин Иванович - директор Института химии ДВО РАН, заведующий отделом строения вещества, академик РАН, доктор химических наук, тел. (4232) 31-25-90, e-mail: sergienkovi@yandex.ru лись на персональном компьютере. Сканирующая электронная микроскопия (СЭМ) ЛГШ выполнена на электронном сканирующем микроскопе высокого разрешения S5500 (Hitachi, Япония). Электропроводность материала определяли методом импедансной спектроскопии с помощью системы Impedance/Gain-phase analyzer SI 1260 (Solartron, Великобритания). Состав газовой среды в разряженном ЛИТ анализировали на газовом хроматографе GC-2010 (Shimadzu, Япония) с микрокатарометром $\mu$ TCD. Хроматографическое разделение выполняли с использованием колонки MOL Sieve 5A PLOT $30 \mathrm{м} \times 0,32$ мм I.D. (Supelco-SigmaAldrich, США). 
Перед применением в качестве катодного материала лигнин Класона был подвергнут предварительному механическому измельчению. Изготовление источника тока производили в сухом боксе 890-NB (PlasLabs, CША) в атмосфере аргона. В качестве ячейки использовали стандартное двухэлектродное устройство STC-19 (MTI, США). Анодом элемента служил диск металлического лития толщиной 0,1 мм. Катодный материал представлял собой смесь активного компонента, т.е. ЛГШ (75 масс.\%), связующего вещества (10 масс.\%) и электропроводной добавки (15 масс.\%), в качестве которых использовались, соответственно, фторопластовая суспензия Ф-4Д (Дальхимия, РФ) и ацетиленовая сажа Lib-CGP (MTI, CША). Компоненты катодной смеси дозировали на аналитических весах AUW120D (Shimadzu, Япония), после чего перемешивали. Готовую катодную пасту наносили на токосъемник - сетчатый плоский диск диаметром 13 мм из нержавеющей стали. Изготовленный таким образом электрод подвергался сушке в печи DZF-6020-110P (MTI, США) при $110^{\circ} \mathrm{C}$ до постоянного веса, с последующей подпрессовкой между двумя стальными пластинами при давлении 12 МПа. Дополнительную термообработку рабочего электрода производили в течение 2 ч при $250{ }^{\circ} \mathrm{C}$. В качестве электролита использован 1 M раствор тетрафторбората лития $\mathrm{LiBF}_{4}$ в смеси пропиленкарбоната и диметоксиэтана в соотношении $3: 1$ (ЭКОТЕХ, РФ). Сепаратор, изготовленный из полипропиленового нетканого материала (Каменскволокно, РФ), прокладывали между литиевым анодом и катодом для предотвращения короткого замыкания. Релаксация системы после сборки для стабилизации напряжения разомкнутой цепи (НРЦ) элемента составляла не менее 12 ч.

Гальваностатический разряд литиевых источников тока Li/ЛГШ при плотностях тока 75 и 100 мкА/см² проводился при комнатной температуре с помощью системы Analytical Celltest System (Solartron, Великобритания), включающей потенциостат/гальваностат 1470Е и анализатор частотного отклика FRA 1455. За основные критерии качества катодного материала были приняты удельная практическая емкость $(Q)$ и разрядное напряжение $(U)$ относительно $\mathrm{Li} / \mathrm{Li}^{+}$. Для получения достоверных результатов измерения проводили как минимум на 6 однотипных ячейках.

\section{Результаты и обсуждение}

Физико-химические особенности лигнина Класона. Влияние дисперсности частии на разрядные характеристики Li/ЛГШ. Содержание элементов в ЛГШ, определенное методом энергодисперсионного анализа, следующее (масс. \%): углерода - 61,9, кислорода - 32,1. Неорганических компонентов (золы) - примерно 0,9 масс. \%. Следует отметить повышенное содержание кислорода в составе ЛГШ в сравнении с гидролизным лигнином, катодные свойства которого изучены авторами работ [11-13]. Согласно токообразующим реакциям, представленным в [14-17], концентрация кислорода определяет значение максимальной удельной емкости химического источника тока системы литий/лигнин.

По данным СЭМ, каждая частица лигнина ГШ имеет на поверхности развитую систему микрои макропор (рис. 1), что может в существенной степени облегчить твердотельную диффузию катионов лития в объеме катода при работе литиевого источника тока на основе лигнина. В то же время наличие в ЛГШ относительно крупных частиц размером до 300 мкм снижает площадь границы раздела электролит/катод.

Для повышения дисперсности ЛГШ механически измельчали. Влияние степени измельчения на параметры ЛИТ оценивали с использованием как ручного, так и автоматического режимов измельчения, в агатовой ступке и в мельнице KM1 (Janetzki, Польша) соответственно. Согласно данным СЭМ, максимальный размер частиц лигнина, образующихся в результате ручного помола, превышает 100 мкм (рис. 2а), измельчение же ЛГШ в мельнице приводит к получению частиц, 70 \% из которых имеют размер 15 мкм (рис. 2б).

Разрядные кривые Li/ЛГШ элементов, полученные в гальваностатическом режиме при плотности тока 100 мкА $/ \mathrm{cm}^{2}$ (рис. 3), показывают, что практическая удельная емкость ЛИТ с катодом на основе измельченного в мельнице лигнина ГШ составляет бо́льшую величину (215 мА·ч/г) по сравнению с $Q$ источника тока на основе ЛГШ, измельченного в ручном режиме (150 мА·ч/г). Полученные экспериментальные данные свидетельствуют о существенном влиянии степени механического измельчения материалов на характеристики ЛИТ. Повышенная дисперсность активного компонента обеспечивает бо́льшую площадь контакта между катодным материалом и электролитом системы Li/ЛГШ.

По результатам импедансной спектроскопии лигнин, извлеченный из шелухи гречихи, обладает невысокой удельной электронной проводимостью $\left(10^{-9} \mathrm{CM} / \mathrm{cm}\right)$. В то же время применяемые сегодня в при конструировании ЛИТ некоторые электродные материалы, например, $\left(\mathrm{CF}_{x}\right)_{n}$ соединения, $\mathrm{Li}_{4} \mathrm{Ti}_{5} \mathrm{O}_{12}$, нитроксильные радикалы и другие характеризуются меньшей электропроводностью (до $10^{-15} \mathrm{CM} / \mathrm{cm}$ ). Обычно при формировании катодной массы на основе непроводящих материалов применяют электропроводные добавки в количестве, не превышающем 50 масс. \% [20-24]. 

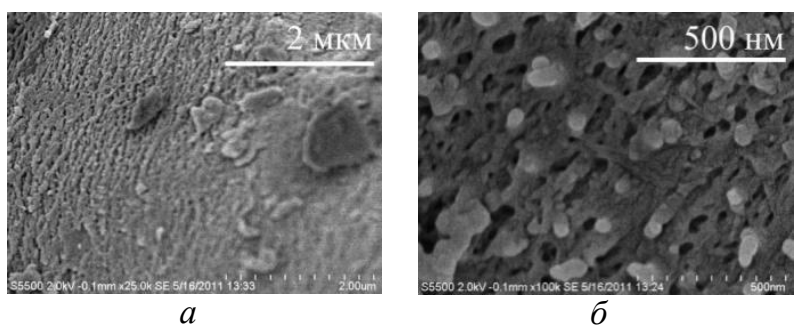

Рис. 1. Сетчатая морфологическая структура растительного лигнина, оцененная методом СЭМ при различном увеличении

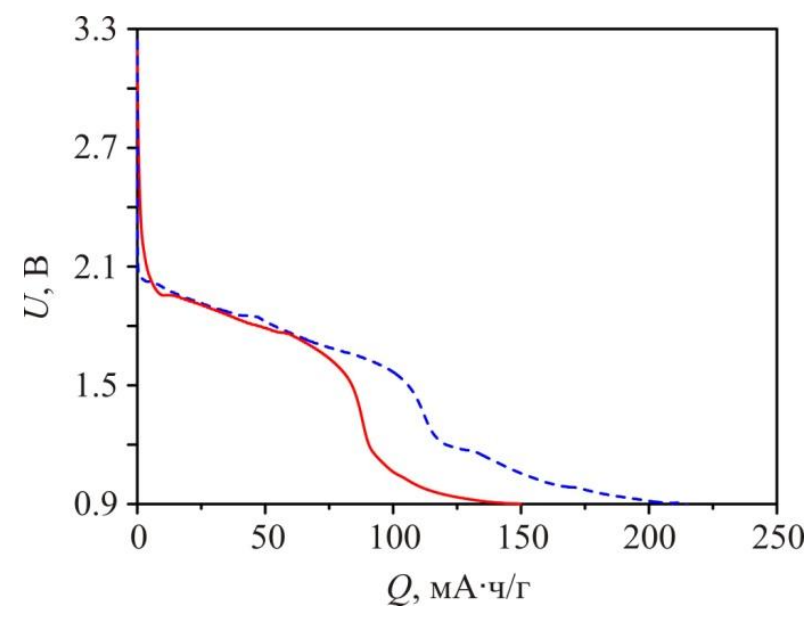

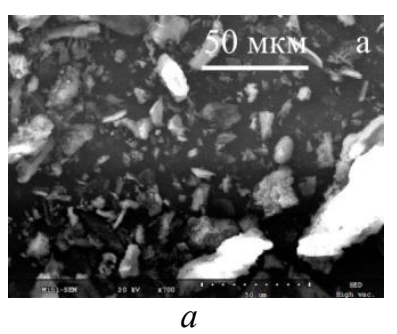

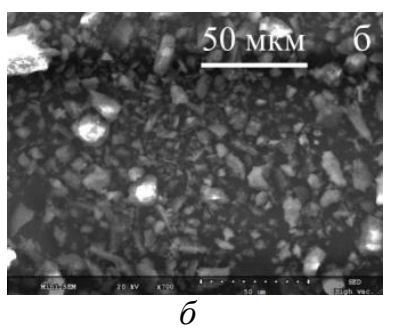

Рис. 2. Дисперсность ЛГШ в зависимости от режима измельчения: $a-$ в агатовой ступке; б - в мельнице KM1 (Janetzki, Польша)

Рис. 3. Гальваностатические характеристики катодных материалов (при плотности тока 100 мкА/см²), содержащих механически измельченный ЛГШ в ручном (сплошная линия) и автоматическом (прерывистая линия) режимах

Параметры электрохимической системы Li/ЛГШ. Результаты гальваностатического исследования системы Li/ЛГШ при плотности тока 75 мкA/см² представлены на рисунке 4. В начале гальваностатического разряда литиевого элемента наблюдается достаточно резкое снижение напряжения источника тока до значения, близкого к 2 В. Время снижения напряжения элемента составляет 3 ч. Резкое падение напряжения на начальной стадии разряда, вероятно, связано как с протеканием электрохимических реакций, обусловленных сложным составом лигнина, так и с формированием поверхностной пленки (изолирующего полифункционального слоя, solid electrolyte interface) [26-29].

На разрядной кривой источника тока Li/ЛГШ отчетливо заметно наличие двух участков с небольшими углами наклона (рис. 4). К плато можно отнести отрезки в диапазонах 2-1,5 В и 1-0 В. Подобный характер разрядной кривой, свидетельствующий о стадийности токообразующего процесса, определяется значениями потенциала реакций взаимодействия ионов лития с кислородом различных функциональных групп, входящих в состав лигнина. Полученные результаты согласуются с литературными данными. Например, в [30] отмечается, что в диапазоне напряжений 3,3-1,5 В протекает электрохимическая реакция между катионами $\mathrm{Li}^{+}$и $\mathrm{C}=\mathrm{O}$ группами полимерного материала, в то время как диапазон 1,5-1 В соответствует взаимодействию Li с гидроксильными группировками. Таким образом, разрядная кривая в диапазоне НРЦ-1,5 В, соответствующая отрезку протяженностью 125 мА·ч/г, обусловлена, вероятно, участием в токообразующей реакции карбонильных групп катодного материала ЛГШ (1). Дальнейший разряд ЛИТ, сопровождаемый падением напряжения, связан, по-видимому, с электрохимическим восстановлением гидроксильных групп лигнина (2). При этом присутствие газообразного водорода в разряженном ХИТ системы Li/ГЛ было подтверждено методом газовой хроматографии. В диапазоне 1-0 B возможно протекание реакции между катионами $\mathrm{Li}^{+}$и $\mathrm{C}-\mathrm{O}-\mathrm{C}$ группами ЛГШ (3). Реакционный механизм взаимодействия $\mathrm{Li}^{+}$с C-OС подробно изучен на примере ряда апротонных диполярных растворителей в работах $[27,31,32]$.

$$
-\underset{l}{\mathrm{C}}=\mathrm{O}+\mathrm{Li}^{+}+\mathrm{e}^{-} \rightarrow-\underset{\mid}{\mathrm{C}}-\mathrm{O}-\mathrm{Li}
$$




$$
\begin{gathered}
2 \mathrm{C}_{6}-\mathrm{C}_{3}-\mathrm{OH}+2 \mathrm{Li}^{+}+2 \mathrm{e}^{-} \rightarrow 2 \mathrm{C}_{6}-\mathrm{C}_{3}-\mathrm{O}-\mathrm{Li}+\mathrm{H}_{2} \\
\mathrm{C}_{6}-\mathrm{C}_{3}-\mathrm{O}-\mathrm{R}+2 \mathrm{Li}^{+}+2 \mathrm{e}^{-} \rightarrow \mathrm{C}_{6}-\mathrm{C}_{3}-\mathrm{O}-\mathrm{Li}+\mathrm{R}-\mathrm{Li}
\end{gathered}
$$

где $\left(\mathrm{C}_{6}-\mathrm{C}_{3}\right)$ - фенилпропановая структурная единица лигнина, $\mathrm{R}:\left(\mathrm{C}_{6}-\mathrm{C}_{3}\right) ; \mathrm{CH}_{3}$.

Следует отметить, что небольшой вклад в разрядную емкость, полученную на участке $1-0$ B, помимо основной реакции лития с активным компонентом катодного материала, может также давать электрохимическое взаимодействие ионов $\mathrm{Li}^{+}$с сажей, используемой в качестве электропроводной добавки, которое (относительно $\mathrm{Li}_{\mathrm{Li}}^{+}$) протекает преимущественно при напряжении ниже 1 В [33-35]. Вклад электропроводной добавки в разрядную емкость элементов системы литий/лигнин был оценен посредством гальваностатического разряда ЛИТ при плотности тока 75 мкА/см². Катодный материал при этом представлял собой смесь сажи (90 масс. \%) и связующего вещества - политетрафторэтилена (10 масс. \%). Согласно полученным данным электрохимическое восстановление сажи дает вклад около $10 \%$ при $U<1$ В. Результаты согласуются с данными других исследователей [33-35].

Таким образом, значения удельной разрядной емкости системы Li/ЛГШ в результате непрерывного гальваностатического разряда до 0,9 В при плотностях тока 75 и 100 мкА/см² составляют около 230 и 215 мА·ч/г соответственно. Полученные данные, в сочетании с низкой себестоимостью лигнина, позволяют говорить о перспективности использования элемента Li/ЛГШ в различных маломощных устройствах. По разрядным характеристикам система Li/ЛГШ сопоставима с традиционными солевыми и щелочными $\mathrm{Zn} / \mathrm{MnO}_{2}$ элементами, практическая разрядная емкость которых составляет около 25 и 130 мА·ч/г соответственно (расчет на единицу катодной массы) [36, 37]. Также следует заметить, что более емкие и мощные литиевые 1,5-вольтовые системы, например $\mathrm{Li} / \mathrm{CuO}$ (при плотности тока порядка единиц мкА/см² емкость достигает 670 мА·ч/г), характеризуются существенно большей себестоимостью [33].

Рис. 4. Гальваностатическая разрядная кривая ЛИТ системы Li/ЛГШ при плотности тока 75 мкA/ $\mathrm{cm}^{2}$

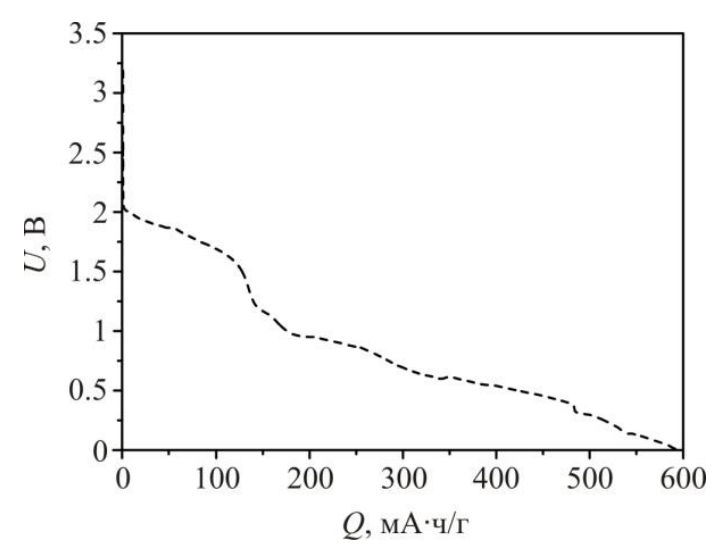

Зависимость параметров системы Lі/ЛГШ от температуры предварительной обработки катодного материала. Для удаления поверхностно-активных веществ, входящих в состав водной суспензии Ф-4Д, используемой в качестве связующего вещества, а также для упрочнения катодных материалов посредством полимеризации необходимой процедурой является дополнительная термическая обработка электрода.

Как показывают данные ДТА и ТГА (рис. 5а), для связующего вещества Ф-4Д характерен экзоэффект при $177^{\circ} \mathrm{C}$, что, по-видимому, связано с полимеризацией и структурированием фторопласта. Окисление поверхностно-активных веществ, сопровождающееся потерей массы, наблюдается в диапазоне от 200 до $250{ }^{\circ} \mathrm{C}$, о чем свидетельствует экзоэффект с пиком при $227^{\circ} \mathrm{C}$. Ярко выраженный эндоэффект при $337{ }^{\circ} \mathrm{C}$ обусловлен плавлением связующего вещества.

При термическом анализе лигнина ГШ (рис. 5б) до $100{ }^{\circ} \mathrm{C}$ отмечается незначительная (около 8 масс. \%) потеря массы, связанная преимущественно с удалением сорбированной на поверхности воды. При последующем нагревании материала наблюдается экзотермический эффект, сопровождающийся дальнейшей потерей массы, что обусловлено, согласно [38, 39], окислением ЛГШ. Потеря массы лигнина в результате его нагревания до $250{ }^{\circ} \mathrm{C}$ составила 18 масс. \%.

Таким образом, основываясь на результатах термического анализа связующего вещества Ф4-Д (рис. 5а) и лигнина ГШ (рис. 5б), в работе исследованы электрические характеристики катодных материалов, как просушенных при температуре, не превышающей $120^{\circ} \mathrm{C}$ (рис. 3), так и подвергнутых термообработке при $250{ }^{\circ} \mathrm{C}$ (рис. 6). 

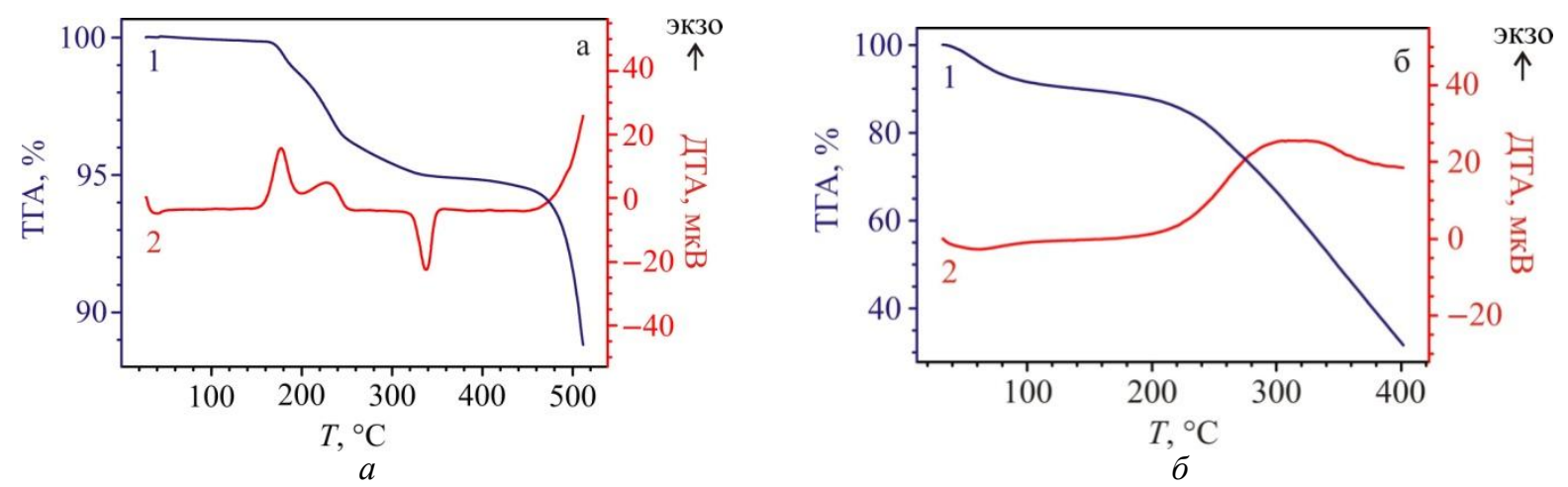

Рис. 5. ТГА (1) и ДТА (2) кривые: $a$ - фторопластового связующего Ф-4Д; 6 - лигнина ГШ

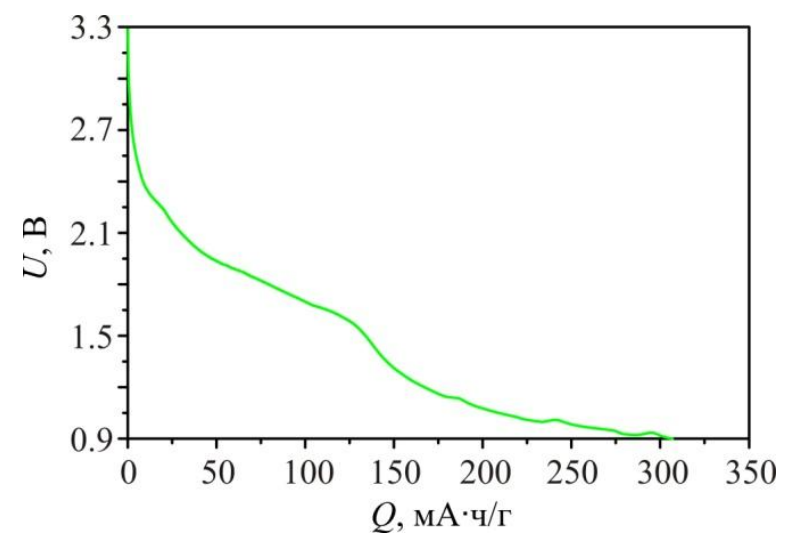

Рис. 6. Кривая $U(Q)$, полученная в результате гальваностатического разряда при 100 мкА/см² литиевого элемента с ЛГШ катодом, подвергнутым термообработке при $250{ }^{\circ} \mathrm{C}$

Анализ результатов исследования гальваностатического разряда элемента системы Li/ЛГШ при плотности тока 100 мкА/см² (рис. 6) позволяет утверждать, что дополнительная термическая обработка катодного материала на основе лигнина ГШ положительно влияниет на электрохимическое поведение источников тока. Удельная разрядная емкость ЛИТ с катодом на основе ЛГШ, подвергнутым термической обработке при $250{ }^{\circ} \mathrm{C}$, достигает 315 мА·ч/г, что существенно выше, чем в случае с электродом без термической обработки (рис. 3). Повышение разрядной емкости ЛИТ, по-видимому, обусловлено полимеризацией связующего вещества, а следовательно, улучшением механического и электрического контакта между частицами катодной массы. Кроме того, в результате выдержки электрода при $250{ }^{\circ} \mathrm{C}$ разрушаются поверхностно-активные вещества, оказывающие отрицательное воздействие на параметры электрохимической системы Li/ЛГШ. Полученные результаты свидетельствуют о целесообразности сушки электрода при $250{ }^{\circ} \mathrm{C}$ перед его использованием в ЛИТ, для получения источников питания длительного функционирования. Согласно данным, значение НРЦ системы Li/ЛГШ не зависит от температуры обработки катодного материала и составляет 3,4 B. B то же время установлено повышение величины разрядного напряжения электрохимической системы Li/JГШ, a следовательно, мощности ЛИТ в результате выдержки катода при $250{ }^{\circ} \mathrm{C}$.

\section{Bыbодbl}

Для литиевых источников тока предложен новый ресурсосберегающий электродный материал на основе лигнина Класона, полученного при делигнификации шелухи гречихи (род Fagópyrum Mill.). Проведен анализ степени измельчения катодного материала на электрохимические характеристики литиевого источника тока. Методом гальваностатического разряда установлено, что химический источник тока системы литий/лигнин Класона характеризуется высокой удельной практической емкостью вплоть до 600 мА·ч/г. Показано, что дополнительная термообработка катода при $250{ }^{\circ} \mathrm{C}$ способствует повышению полезной (в диапазоне от 3,4 до 0,9 В) удельной разрядной емкости на 30\%, т.е. до 315 мА·ч/г. Установлено, что в результате выдержки катода при $250{ }^{\circ} \mathrm{C}$ увеличивается величина разрядного напряжения и, следовательно, мощность электрохимической системы. Обоснованы токообразующие реакции, имеющие место в электрохимическом элементе литий/лигнин Класона. Полученные значения электрических эксплуатационных параметров разработанного литиевого источника тока показывают перспективность использования разработанных первичных ЛИТ для питания различных устройств малой мощности. 
Авторы выражают признательность к.х.н. С.В. Суховерхову (ИХ ДВО РАН, Владивосток) за проведение газохроматографических исследований, к.х.н. В.Г. Курявому (ИХ ДВО РАН, Владивосток) за исследование образиов методом сканирующей электронной микроскопии.

\section{Список литературы}

1. Chen H., Armand M., Demailly G., Dolhem F., Poizot P., Tarascon J.-M. From biomass to a renewable $\mathrm{Li}_{\mathrm{x}} \mathrm{C}_{6} \mathrm{O}_{6}$ organic electrode for sustainable Li-ion batteries // ChemSusChem. 2008. M. 1. Pp. 348-355.

2. Zeng R.-H., Li X.-P., Qiu Y.-C., Li W.-S., Yi J., Lu D.-S., Tan C.-L., Xu M.-Q. Synthesis and properties of a lithiumorganic coordination compound as lithium-inserted material for lithium ion batteries // Electrochemistry Communications. 2010. Vol. 12. Pp. 1253-1256.

3. Chen H., Armand M., Courty M., Jiang M., Grey C.P., Dolhem F., Tarascon J.-M., Poizot P. Lithium salt of tetrahydroxybenzoquinone: toward the development of a sustainable Li-ion battery // Journal of the American Chemical Society. 2009. Vol. 131. Pp. 8984-8988.

4. Каневский Л.С. Проблема рекуперации и утилизации литиевых источников тока // Электрохимическая энергетика. 2005. Т. 5, №3. С. 209-214.

5. Lisbona D., Snee T. A review of hazards associated with primary lithium and lithium-ion batteries // Process Safety and Environmental Protection. 2011. Vol. 89. Pp. 434-442.

6. Лазарева Е.Н. Кинетические закономерности и механизм формирования интеркалятов лития в углеграфитовых материалах по методу катодного внедрения: дисс. ... канд. хим. наук. Саратов, 2004. 194 с.

7. Karlsson C., Jämstorp E., Strømme M., Sjödin M. Computational electrochemistry study of 16 isoindole-4,7-diones as candidates for organic cathode materials // Journal of Chemical Physics C. 2012. Vol. 116. Pp. 3793-3801.

8. Kim J.-K., Thébault F., Heo M.-Y., Kim D.-S., Hansson Ö., Ahn J.-H., Johansson P., Öhrström L., Matic A., Jacobsson P. 2,3,6,7,10,11-Hexamethoxytriphenylene (HMTP): A new organic cathode material for lithium batteries // Electrochemistry Communications. 2012. Vol. 21. Pp. 50-53.

9. Lee S.H., Kim J.-K., Cheruvally G., Choi J.-W., Ahn J.-H., Chauhan G.S., Song C.E. Electrochemical properties of new organic radical materials for lithium secondary batteries // Journal of Power Sources. 2008. Vol. 184. Pp. 503-507.

10. Milczarek G., Inganäs $O$. Renewable cathode materials from biopolymer/conjugated polymer interpenetrating networks // Science. 2012. Vol. 335. Pp. 1468-1471.

11. Опра Д.П., Гнеденков С.В., Синебрюхов С.Л., Цветников А.К., Сергиенко В.И. Высокоэнергоемкие литиевые источники тока на основе гидролизного лигнина // Вестник ДВО РАН. 2012. №2. С. 111-116.

12. Gnedenkov S.V., Opra D.P., Sinebryukhov S.L., Tsvetnikov A.K., Ustinov A.Y., Sergienko V.I. Hydrolysis ligninBased Organic Electrode material for primary lithium batteries // Journal of Solid State Electrochemistry. 2013. Vol. 17, №10. Pp. 2611-2621.

13. Гнеденков С.В., Опра Д.П., Синебрюхов С.Л., Цветников А.К., Устинов А.Ю., Сергиенко В.И. Литиевые химические источники тока на основе гидролизного лигнина // Электрохимическая энергетика. 2013. Т. 13, №1. C. 23-33.

14. Гнеденков С.В., Опра Д.П., Синебрюхов С.Л., Цветников А.К., Устинов А.Ю., Сергиенко В.И. Характеристики литиевых источников тока на основе гидролизного лигнина // Вестник ДВО РАН. 2013. №5. С. 12-22.

15. Gnedenkov S.V., Opra D.P., Sinebryukhov S.L., Tsvetnikov A.K., Ustinov A.Y., Sergienko V.I. Hydrolysis Lignin: electrochemical properties of the organic cathode material for primary lithium battery // Journal of Industrial and Engineering Chemistry. 2014. Vol. 20. Pp. 903-910.

16. Пат. 2482571 (РФ). Способ получения катодного материала для химических источников тока / А.К. Цветников, Д.П. Опра, Л.А. Матвиенко, С.Л. Синебрюхов, С.В. Гнеденков, В.И. Сергиенко. 2013, №14. С. 8.

17. Вураско А.В., Минакова А.Р., Дрикер Б.Н. Кинетика окислительно-органосольвентной делигнификации недревесного растительного сырья // Химия растительного сырья. 2010. №1. С. 35-40.

18. Патрушева О.В., Ковехова А.В., Барышева В.С., Земнухова Л.А. Лигнины Классона плодовых оболочек риса, гречихи и подсолнечника // Химия и технология растительных веществ: тез. докл VIII Всерос. конф. Калининград; Сыктывкар, 2013. С. 176.

19. Никитин В.М., Оболенская А.В., Щёголев В.П. Химия древесины и целлюлозы. М., 1978. 368 с.

20. Gnedenkov S.V., Tsvetnikov A.K., Opra D.P., Sinebryukhov S.L., Sergienko V.I. Fluorocarbon materials produced by the thermo destruction of polytetrafluoroethylene and possibility of theirs application in $\mathrm{Li} /\left(\mathrm{CF}_{x}\right)_{n}$ batteries // Physics Procedia. 2012. Vol. 23. Pp. 86-89.

21. Митькин В.Н. Новейшие электродные материалы для литиевой химической энергетики. Новосибирск, 2001. 162 с.

22. Лиу К.М., Чен Ж., Ван Ф.К., Йи Б.Л. Улучшение электрохимических свойств поли(4-метакрилоилокси2,2,6,6-тетраметил-пиперидин- $N$-оксилового) катода с помощью саж с большой удельной площадью поверхности // Электрохимия. 2012. Т. 48, №11. С. 1155-1160.

23. Lam P., Yazami R. Physical characteristics and rate performance of $\left(\mathrm{CF}_{x}\right)_{n}(0.33<\mathrm{x}<0.66) / /$ Journal of Power Sources. 2006. Vol. 153. C. 354-359.

24. Вовчук В.Е., Митькин В.Н., Галицкий А.А., Кузовников А.М. Разработка усовершенствованных методов неразрушающей диагностики промышленных и опытных литиевых источников тока // Электрохимическая энергетика. 2007. Т. 7, №2. С. 103-114.

25. Schweikert N., Hahn H., Indris S. Cycling behaviour of $\mathrm{Li} / \mathrm{Li}_{4} \mathrm{Ti}_{5} \mathrm{O}_{12}$ cells studied by electrochemical impedance spectroscopy // Physical Chemistry Chemical Physics. 2011. Vol. 13. Pp. 6234-6240.

26. Кедринский И.А., Дмитренко В.Е., Грудянов И.И. Литиевые источники тока. М., 1992. 240 с.

27. Кедринский И.А., Дмитренко В.Е., Поваров Ю.М., Грудянов И.И. Химические источники тока с литиевым электродом. Красноярск, 1983. 247 с. 
28. Dey A.N. Lithium anode film and organic and inorganic electrolyte batteries // Thin Solid Films. 1977. Vol. 43. Pp. 131-171.

29. Aurbach D., Zaban A., Ein-Eli Y., Weissman I., Chusid O., Markovsky B., Levi M., Levi E., Schechter A., Granot E. Recent studies on the correlation between surface chemistry, morphology, three-dimensional structures and performance of $\mathrm{Li}$ and $\mathrm{Li}-\mathrm{C}$ intercalation anodes in several important electrolyte systems // Journal of Power Sources. 1997. Vol. 68. Pp. 91-98.

30. Zhao L., Wang W., Wang A., Yuan K., Chen S., Yang Y. A novel polyquinone cathode material for rechargeable lithium batteries // J. Power Sources. 2013. Vol. 233. Pp. 23-27.

31. Львов А.Л. Литиевые химические источники тока // Соросовский образовательный журнал. 2001. №7. С. 45-51.

32. Andersson A. Surface phenomena in Li-ion batteries : dis.... Ph. D. in inorg. chem. Uppsala, 2001. 54 p.

33. Walker W., Grugeon S., Mentre O., Laruelle S., Tarascon J.-M., Wudl F. Ethoxycarbonyl-based organic electrode for Li-batteries // Journal of the American Chemical Society. 2010. Vol. 132. Pp. 6517-6523.

34. Novák P., Podhájecký P. A high temperature lithium-copper oxide cell with a solid polymer electrolyte // Journal of Power Sources. 1991. Vol. 35. Pp. 235-247.

35. Gao X.P., Bao J.L., Pan G.L., Zhu H.Y., Huang P.X., Wu F., Song D.Y. Preparation and electrochemical performance of polycrystalline and single crystalline $\mathrm{CuO}$ nanorods as anode materials for $\mathrm{Li}$ ion battery // Journal of Physical Chemistry B. 2004. Vol. 108. Pp. 5547-5551.

36. Кебадзе Ж.М., Какурия Л.Ш., Пруидзе В.П. Использование углеродного волокнистого материала для повышения электротехнических характеристик элемента Лекланше // Электрохимическая энергетика. 2005. T. 5, №4. C. 241-245.

37. Minakshi M., Ionescu M. Anodic behavior of zinc in $\mathrm{Zn}-\mathrm{MnO}_{2}$ battery using ERDA technique // International Journal of Hydrogen Energy. 2010. Vol. 35. Pp. 7618-7622.

38. Грибков И.В. Химический состав и строение технического гидролизного лигнина: дисс. ... канд. хим. наук. СПб., 2008. 142 c.

39. Opra D.P., Gnedenkov S.V., Sinebryukhov S.L., Tsvetnikov A.K., Sergienko V.I. Fabrication of battery cathode material based on hydrolytic lignin // Solid State Phenomena. 2014. Vol. 213. Pp. 154-159.

Поступило в редакиию 31 июля 2014 г.

После переработки 9 февраля 2015 г. 
Gnedenkov S.V. ${ }^{l}$, Opra D.P. ${ }^{1 *}$, Zemnukhova L.A. ${ }^{l}$, Sinebryukhov S.L. ${ }^{l}$, Minaev A.N. ${ }^{1}$, Kedrinskii I.A. ${ }^{2}$, Sergienko V.I. ${ }^{1}$ KLASON LIGNIN AS A POSITIVE ELECTRODE MATERIAL FOR LITHIUM BATTERY

${ }^{1}$ Institute of Chemistry, Far Eastern Branch of Russian Academy of Sciences, 100-letiia Vladivostoka av,, 159,

Vladivostok, 690022 (Russia),e-mail: ayacks@mail.ru

${ }^{2}$ Siberian State Technological University, Mira av., 82, Krasnoyarsk, 660049 (Russia)

For the first time the availability of Klason lignin extracted from the buckwheat (the genus Fagópyrum Mill.) husks as positive electrode material for lithium batteries has been demonstrated. Physicochemical characterization of Klason lignin was carried out. The dependence of the electrochemical behavior (vs. $\mathrm{Li} / \mathrm{Li}^{+}$) of the Klason lignin on the milling degree was evaluated. The maximum specific capacity of lignin was equal to $600 \mathrm{mAh} / \mathrm{g}$ at a discharge rate of $75 \mu \mathrm{A} / \mathrm{cm}$. Beneficial effect of the thermal pretreatment of the Klason lignin cathode at $250{ }^{\circ} \mathrm{C}$ on the battery performance was established. It was found that the discharge capacity of the battery increased by $30 \%$ in the range from 3,3 to $0,9 \mathrm{~V}$ for the pretreated cathode material.

Keywords: Klason lignin, lithium battery, organic electrode material, buckwheat husks.

\section{References}

1. Chen H., Armand M., Demailly G., Dolhem F., Poizot P., Tarascon J.-M. ChemSusChem, 2008, vol. 1, pp. 348-355.

2. Zeng R.-H., Li X.-P., Qiu Y.-C., Li W.-S., Yi J., Lu D.-S., Tan C.-L., Xu M.-Q. Electrochemistry Communications, 2010, vol. 12, pp. 1253-1256.

3. Chen H., Armand M., Courty M., Jiang M., Grey C.P., Dolhem F., Tarascon J.-M., Poizot P. Journal of the American Chemical Society, 2009, vol. 131, pp. 8984-8988.

4. Kanevskii L.S. Elektrokhimicheskaia energetika, 2005, vol. 5, no. 3, pp. 209-214. (in Russ.).

5. Lisbona D., Snee T. Process Safety and Environmental Protection, 2011, vol. 89, pp. 434-442.

6. Lazareva E.N. Kineticheskie zakonomernosti $i$ mekhanizm formirovaniia interkaliatov litiia $v$ uglegrafitovykh materialakh po metodu katodnogo vnedreniia: dis. ... kand. khim. nauk. [Kinetics and mechanism of the formation of lithium intercalation in carbon materials by the method of cathodic introduction: the dissertation Candidate of Chemical Science]. Saratov, 2004, 194 p. (in Russ.).

7. Karlsson C., Jämstorp E., Strømme M., Sjödin M. Journal of Chemical Physics C, 2012, vol. 116, pp. 3793-3801.

8. 163. Kim J.-K., Thébault F., Heo M.-Y., Kim D.-S., Hansson Ö., Ahn J.-H., Johansson P., Öhrström L., Matic A., Jacobsson P. Electrochemistry Communications, 2012, vol. 21, pp. 50-53.

9. Lee S.H., Kim J.-K., Cheruvally G., Choi J.-W., Ahn J.-H., Chauhan G.S., Song C.E. Journal of Power Sources, 2008, vol. 184, pp. 503-507.

10. Milczarek G., Inganäs O. Science, 2012, vol. 335, pp. 1468-1471.

11. Opra D.P., Gnedenkov S.V., Sinebriukhov S.L., Tsvetnikov A.K., Sergienko V.I. Vestnik DVO RAN, 2012, no. 2 , pp. 111-116. (in Russ.).

12. Gnedenkov S.V., Opra D.P., Sinebryukhov S.L., Tsvetnikov A.K., Ustinov A.Y., Sergienko V.I. Journal of Solid State Electrochemistry, 2013, vol. 17, №10, pp. 2611-2621.

13. Gnedenkov S.V., Opra D.P., Sinebriukhov S.L., Tsvetnikov A.K., Ustinov A.Iu., Sergienko V.I. Elektrokhimicheskaia energetika, 2013, vol. 13, no.1, pp. 23-33. (in Russ.).

14. Gnedenkov S.V., Opra D.P., Sinebriukhov S.L., Tsvetnikov A.K., Ustinov A.Iu., Sergienko V.I. Vestnik DVO RAN, 2013, no. 5, pp. 12-22. (in Russ.).

15. Gnedenkov S.V., Opra D.P., Sinebryukhov S.L., Tsvetnikov A.K., Ustinov A.Y., Sergienko V.I. Journal of Industrial and Engineering Chemistry, 2014, vol. 20, pp. 903-910.

16. Patent 2482571 (RU). 2013. (in Russ.).

17. Vurasko A.V., Minakova A.R., Driker B.N. Khimiia rastitel'nogo syr'ia, 2010, no. 1, pp. 35-40. (in Russ.).

18. Patrusheva O.V., Kovekhova A.V., Barysheva V.S., Zemnukhova L.A. Khimiia i tekhnologiia rastitel'nykh veshchestv: tez. dokl. VIII Vseros. konf. [Chemistry and Technology of Plant Substances: abstracts of VIII All-Russian Conference]. Kaliningrad; Syktyvkar, 2013, p. 176. (in Russ.).

19. Nikitin V.M., Obolenskaia A.V., Shchegolev V.P. Khimiia drevesiny i tselliulozy. [Chemistry of wood and cellulose]. Moscow, 1978, 368 p. (in Russ.).

20. Gnedenkov S.V., Tsvetnikov A.K., Opra D.P., Sinebryukhov S.L., Sergienko V.I. Physics Procedia, 2012, vol. 23, pp. 86-89.

21. Mit'kin V.N. Noveishie elektrodnye materialy dlia litievoi khimicheskoi energetiki. [Latest electrode materials for lithium chemical power]. Novosibirsk, 2001, 162 p. (in Russ.).

22. Liu K.M., Chen Zh., Van F.K., Ii B.L. Elektrokhimiia, 2012, vol. 48, no. 11, pp. 1155-1160. (in Russ.).

23. Lam P., Yazami R. Journal of Power Sources, 2006, vol. 153, pp. 354-359.

24. Vovchuk V.E., Mit'kin V.N., Galitskii A.A., Kuzovnikov A.M. Elektrokhimicheskaia energetika, 2007, vol. 7, no. 2 , pp. 103-114. (in Russ.).

25. Schweikert N., Hahn H., Indris S. Physical Chemistry Chemical Physics, 2011, vol. 13, pp. 6234-6240.

26. Kedrinskii I.A., Dmitrenko V.E., Grudianov I.I. Litievye istochniki toka. [Lithium power sources]. Moscow, 1992, 240 p. (in Russ.).

27. Kedrinskii I.A., Dmitrenko V.E., Povarov Iu.M., Grudianov I.I. Khimicheskie istochniki toka s litievym elektrodom. [Chemical current sources with a lithium electrode]. Krasnoyarsk, 1983, 247 p. (in Russ.).

28. Dey A.N. Thin Solid Films, 1977, vol. 43, pp. 131-171.

29. Aurbach D., Zaban A., Ein-Eli Y., Weissman I., Chusid O., Markovsky B., Levi M., Levi E., Schechter A., Granot E. Journal of Power Sources, 1997, vol. 68, pp. 91-98.

30. Zhao L., Wang W., Wang A., Yuan K., Chen S., Yang Y. J. Power Sources, 2013, vol. 233, pp. 23-27.

31. L'vov A.L. Sorosovskii obrazovatel'nyi zhurnal, 2001, no. 7, pp. 45-51. (in Russ.).

\footnotetext{
* Corresponding author.
} 
32. Andersson A. Surface phenomena in Li-ion batteries : dis. ... Ph. D. in inorg. chem. Uppsala, 2001. 54 p.

33. Walker W., Grugeon S., Mentre O., Laruelle S., Tarascon J.-M., Wudl F. Journal of the American Chemical Society, 2010, vol. 132, pp. 6517-6523.

34. Novák P., Podhájecký P. Journal of Power Sources, 1991, vol. 35, pp. 235-247.

35. Gao X.P., Bao J.L., Pan G.L., Zhu H.Y., Huang P.X., Wu F., Song D.Y. Journal of Physical Chemistry B, 2004 , vol. 108 , pp. 5547-5551.

36. Kebadze Zh.M., Kakuriia L.Sh., Pruidze V.P. Elektrokhimicheskaia energetika, 2005, vol. 5, no. 4, pp. 241-245. (in Russ.).

37. Minakshi M., Ionescu M. International Journal of Hydrogen Energy, 2010, vol. 35, pp. 7618-7622.

38. Gribkov I.V. Khimicheskii sostav i stroenie tekhnicheskogo gidroliznogo lignina: dis. ... kand. khim. nauk. [The chemical composition and structure of technical hydrolytic lignin: Candidate of Chemical Science dissertation]. Sankt-petersburg, 2008, 142 p. (in Russ.).

39. Opra D.P., Gnedenkov S.V., Sinebryukhov S.L., Tsvetnikov A.K., Sergienko V.I. Solid State Phenomena, 2014, vol. 213, pp. 154-159.

Received July 31, 2014

Revised February 9, 2015 